\title{
TWO NOVEL HOLOSTANE-TYPE GLYCOSIDES FROM THE VISCERA OF SEA CUCUMBER APOSTICHOPUS JAPONICUS WITH ANTITUMOR ACTIVITIES
}

\author{
Xuan-Ming ZHANG, ${ }^{\mathrm{a}}$ Li-Wen HAN, ${ }^{\mathrm{a}}$ Wen-Long SHENG, ${ }^{\mathrm{a}}$ Xiao-Bin LI, ${ }^{\mathrm{a}}$ Shan-Shan ZHANG, ${ }^{\mathrm{a}}$ Qing XIA, \\ Guan-E YANG ${ }^{\mathrm{b}, *}$ and Ke-Chun LIU, ${ }^{\mathrm{a}, *}$ \\ ${ }^{a}$ Key Laboratory for Drug Screening Technology, Biology Institute, Qilu University of Technology (Shandong Academy of Sciences), \\ Jinan, 250103, P.R. China \\ ${ }^{\mathrm{b}}$ School of Pharmaceutical Sciences, Shanxi Medical University, Taiyuan, 030001, P.R. China
}

Received July 14, 2018

Two holostane type glycosides, apostichoposide D (1) and E (2), were isolated from the viscera of the Chinese sea cucumber Apostichopus japonicus Selenka, a traditional tonic of high economic value in China. The structures of the two compounds were elucidated by a combination of 1D, 2D NMR, and HR-MS spectroscopic data as well as acid hydrolysis analysis. Compound 1 had adequate cytotoxic activity against MGC-803 and PC-3M cell lines, and compound $\mathbf{2}$ exhibited adequate inhibitory effect on MGC-803 cell lines. Our results indicate that glycosides present in $A$. japonicus viscera were an important high-value resource.
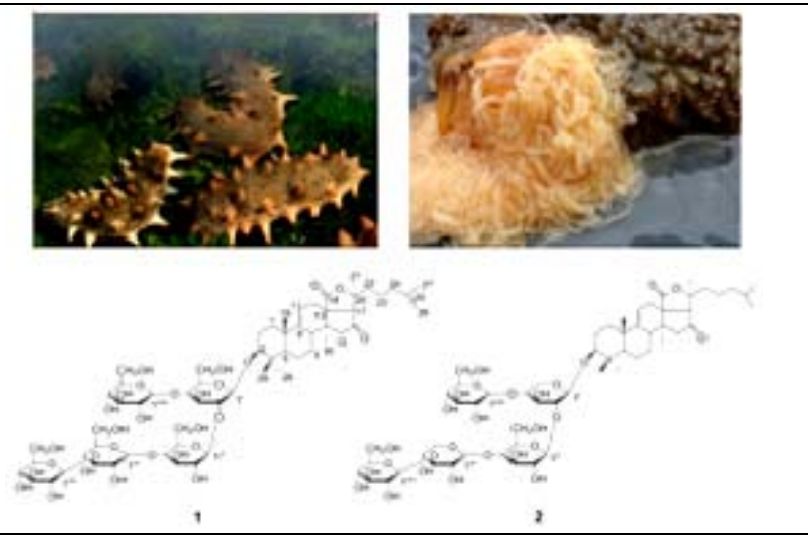

\section{INTRODUCTION}

Sea cucumbers belonging to the class Holothurioidae are soft-bodied wormlike echinoderms, which have long been exploited as a fishery resource in Russia, China, Korea, and Japan. ${ }^{1-3}$ Their diverse secondary metabolites were used in pharmaceutical, nutraceutical, cosmeceutical and agrochemical products. ${ }^{4,5}$ Triterpene glycosides, present in sea cucumber species, have been thoroughly researched. The majority of the glycosides contain holostane-type aglycones-lanostane derivatives with 18(20)-lactone, as opposed to non-holostane aglycones-lanostane derivatives without $18(20)$-lactone. ${ }^{6-9}$ The carbohydrate chains of the glycosides are comprised of two to six monosaccharide units. Sea cucumber glycosides exhibit a wide spectrum of biological activities against cardiovascular diseases, tumors, fungal infections, and hypertension. ${ }^{10-14}$ Due to the presence of multiple proteases in internal organs, the viscera are usually removed to avoid adverse reactions during sea cucumber processing. Recent studies have shown that glycoside levels in sea cucumbers are significantly higher in their viscera than in their body wall. ${ }^{15,16}$ In this study, we analyzed the structure of two novel holostane glycosides from the viscera of

\footnotetext{
*Corresponding author: hliukch@sdas.org; yangguane2004@163.com
} 
Chinese Apostichopus japonicus using ${ }^{1} \mathrm{H},{ }^{13} \mathrm{C}$ NMR spectra, 2D NMR, and HR-ESI mass spectrometry. The cytotoxic activities of the two compounds against human gastric carcinoma MGC-803 cells, human prostate cancer PC-3M cells, and human breast cancer MCF-7 cells were evaluated. Our study findings highlight the diversity and biological activities of glycosides in A. japonicus.

\section{RESULT AND DISCUSSION}

$\mathrm{MeOH}$ extract of $A$. japonicus viscera was loaded onto a D101 macroporous adsorption resin column and eluted with four bed volumes (BV) of 30\% ethanol and four BV of $60 \%$ ethanol. Subsequently, the saponin-rich fraction was eluted with six BV of $90 \%$ ethanol, concentrated, and dried. The residue was subjected to sequential column chromatography, including Sephadex LH-20, silica gel, and RP-18 gel, yielding compounds $\mathbf{1}$ and $\mathbf{2}$. The structures of these two compounds were elucidated by extensive NMR techniques including 1D NMR $\left({ }^{1} \mathrm{H}\right.$ and ${ }^{13} \mathrm{C}$ NMR), 2D NMR, HR-ESI-MS, as well as chemical analysis.

Compound 1 (Fig. 1) was a white amorphous powder with molecular formula $\mathrm{C}_{60} \mathrm{H}_{96} \mathrm{O}_{29}$ based on HR-ESI-MS at m/z $1235.5951\left[\mathrm{M}-\mathrm{H}-\mathrm{CO}_{2}\right]^{-}$, a 44-Da neutral $\mathrm{CO}_{2}$ loss from the 18(20) lactone moiety, ${ }^{17}$ and NMR spectroscopy. The ${ }^{1} \mathrm{H}$ NMR spectrum of compound $\mathbf{1}$ displayed five three-proton singlet signals at $\delta_{\mathrm{H}} 0.95,1.10,1.38$, 1.42 , and 1.48 , indicating the presence of tertiary methyl groups, two three-proton doublets at $\delta_{\mathrm{H}}$ 0.90 and $0.91(J=7.3 \mathrm{~Hz})$ from the secondary methyl groups, and an olefinic proton $\mathrm{H}-11$ at $\delta_{\mathrm{H}}$ 5.32. The ${ }^{13} \mathrm{C}$ NMR spectrum displayed 60 carbon signals and seven methyl groups at $\delta_{\mathrm{C}} 17.9,18.8$, 22.6, 22.8, 22.9, 27.7, and 28.8. The resonances at $\delta_{\mathrm{C}} 146.1(\mathrm{C}-9)$ and $111.1(\mathrm{C}-11)$ were assigned to olefinic carbons. Shielded chemical shifts at $\delta_{\mathrm{C}}$ $213.6(\mathrm{C}-16)$ and $\delta_{\mathrm{C}} 176.5(\mathrm{C}-18)$ suggest the presence of two carboxyl groups. The structure of compound $\mathbf{1}$ is characteristic of the holostane-type skeleton, based on comparison between its ${ }^{1} \mathrm{H}$ and ${ }^{13} \mathrm{C}$ NMR data (Tables 1 and 2) and those of congeners from sea cucumber. Additionally, the ${ }^{1} \mathrm{H}$ NMR spectrum of compound $\mathbf{1}$ revealed five anomeric proton signals at $\delta_{\mathrm{H}} 4.97(1 \mathrm{H}, \mathrm{d}, J=8.0$
$\mathrm{Hz}), 5.25(1 \mathrm{H}, \mathrm{d}, J=8.0 \mathrm{~Hz}), 5.03(1 \mathrm{H}, \mathrm{d}, J=$ $8.0 \mathrm{~Hz}), 5.28(1 \mathrm{H}, \mathrm{d}, J=7.6 \mathrm{~Hz})$, and $5.14(1 \mathrm{H}, \mathrm{d}$, $J=7.2 \mathrm{~Hz}$ ) correlated with five anomeric carbons at $\delta_{\mathrm{C}} 105.6,106.2,103.9,106.4$, and 106.2 in the ${ }^{13} \mathrm{C}$ NMR spectrum, respectively. HMBC cross-peaks (Fig. 2) at $\delta_{\mathrm{H}} 4.97\left(\mathrm{Glc} \mathrm{H}-1^{\prime}\right) / \delta_{\mathrm{C}} 88.5$ (Agly C-3), $\delta_{\mathrm{H}} 5.25$ (Glc H-1")/ $\delta_{\mathrm{C}} 88.1$ (Glc C-2'), $\delta_{\mathrm{H}} 5.03\left(\mathrm{Glc} \mathrm{H}-1{ }^{\prime \prime}\right) / \delta_{\mathrm{C}} 79.1$ (Glc C-4"), $\delta_{\mathrm{H}} 5.28$ (Glc H-1"')/ $/ \delta_{\mathrm{C}} 88.9$ (Glc C-3"'), and $\delta_{\mathrm{H}} 5.14$ (Glc $\left.\mathrm{H}-1^{\prime \prime \prime ')}\right) / \delta_{\mathrm{C}} 79.3$ (Glc C-4') are representative of the 3-O-oligosaccharidic moiety. Acid hydrolysis of compound 1 yielded $\beta$-D-glucose as the only product detectable by HPLC. Therefore, the structure of compound $\mathbf{1}$ was deduced to be holosta-9(11)-en-16-one-3-O-[2-O- $\beta$-D-glucopyran osyl-( $1 \rightarrow 3)-\beta$-D-glucopyranosyl- $(1 \rightarrow 4)-\beta$-D-gluco pyranosyl]-[4-O- $\beta$-D-glucopyranosyl]- $\beta$-D-glucop yranosyl and labeled apostichoposide D.

Compound 2 (Fig. 1) was a white amorphous powder. The HR-ESI-MS spectrum revealed a $[\mathrm{M}-\mathrm{H}]^{-}$ion peak at $\mathrm{m} / \mathrm{z} 1219.5687$ with a molecular formula $\mathrm{C}_{58} \mathrm{H}_{92} \mathrm{O}_{27}$. Analysis of the NMR data of compound $\mathbf{2}$ (Tables 1 and 2) revealed the same aglycone of compound $\mathbf{1}$ and a sugar chain linked at the C-3 hydroxyl group. The ${ }^{1} \mathrm{H}$ NMR spectrum of compound $\mathbf{2}$ showed five anomeric proton signals at $\delta_{\mathrm{H}} 4.75(1 \mathrm{H}, \mathrm{d}, \mathrm{J}=7.3$ $\mathrm{Hz}), 5.26(1 \mathrm{H}, \mathrm{d}, \mathrm{J}=8.4 \mathrm{~Hz}), 5.16(1 \mathrm{H}, \mathrm{d}, \mathrm{J}=7.9$ $\mathrm{Hz}), 5.29(1 \mathrm{H}, \mathrm{d}, \mathrm{J}=7.9 \mathrm{~Hz})$, and $5.00(1 \mathrm{H}, \mathrm{d}, \mathrm{J}=$ $7.4 \mathrm{~Hz}$ ), which correlated with the corresponding anomeric carbon signals at $\delta_{\mathrm{C}} 105.5,106.2,105.8$, 106.4, and 103.1, respectively. The linkages of the five sugars were determined by $\mathrm{HMBC}$ correlations (Fig.2) at $\delta_{\mathrm{H}} 4.75\left(\mathrm{Xyl} \mathrm{H}-1^{\prime}\right) / \delta_{\mathrm{C}} 88.5$ (Agly C-3), $\delta_{\mathrm{H}} 5.26$ (Glc H-1")/ $\delta_{\mathrm{C}} 85.5$ (Xyl C-2'), $\delta_{\mathrm{H}} 5.16\left(\mathrm{Xyl} \mathrm{H}-1^{\prime \prime \prime}\right) / \delta_{\mathrm{C}} 79.1$ (Glc C-4"), $\delta_{\mathrm{H}} 5.29$ $\left(\mathrm{Glc} \mathrm{H}-1^{\prime \prime \prime}\right) / \delta_{\mathrm{C}} 87.9$ (Xyl C-3"'), and $\delta_{\mathrm{H}} 5.00$ (Glc $\left.\mathrm{H}-1{ }^{\prime \prime \prime \prime}\right) / \delta_{\mathrm{C}} 78.5$ (Xyl C-4') (Fig. 2). Acid hydrolysis of compound 2 resulted in $\beta$-D-glucose and $\beta$-D-xylose, which were identified by HPLC contrast. Therefore, the structure of compound 2 was deduced to be holosta-9(11)-en-16-one-3-O-[2-O- $\beta$-D-glucopyran osyl-( $(1 \rightarrow 3)-\beta$-D-xylopyranosyl- $(1 \rightarrow 4)-\beta$-D-glucop yranosyl]-[4-O- $\beta$-D-glucopyranosyl]- $\beta$-D-xylopyra nosyl and labeled apostichoposide $\mathrm{E}$. 


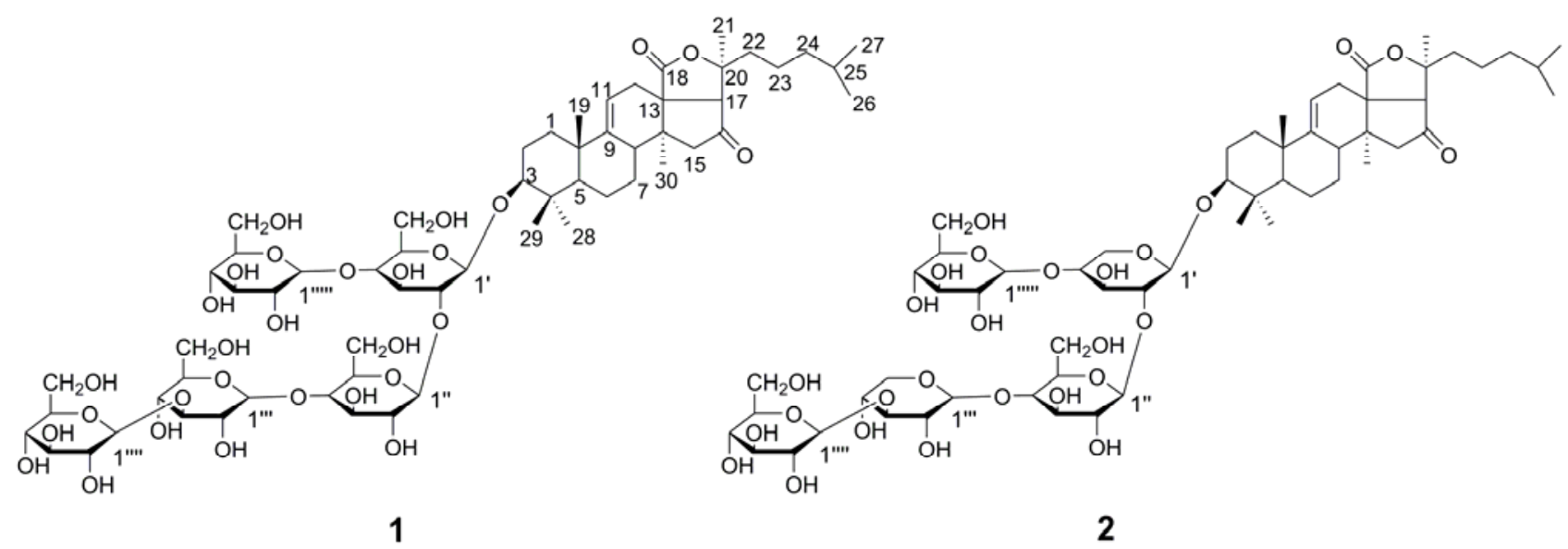

Fig. 1 - Structures of compounds $\mathbf{1}$ and $\mathbf{2}$.

Table 1

${ }^{1} \mathrm{H}$ and ${ }^{13} \mathrm{C}$ NMR spectral data $(400 / 100 \mathrm{MHz})$ of the aglycones of compounds $\mathbf{1}$ and $\mathbf{2}$ in $\mathrm{C}_{5} \mathrm{D}_{5} \mathrm{~N}$

\begin{tabular}{|c|c|c|c|c|}
\hline \multirow{2}{*}{ No. } & \multicolumn{2}{|l|}{1} & \multicolumn{2}{|c|}{2} \\
\hline & $\delta_{\mathrm{H}}$ & $\delta_{\mathrm{C}}$ & $\delta_{\mathrm{H}}$ & $\delta_{\mathrm{C}}$ \\
\hline $\mathrm{C} 1$ & $1.43(\mathrm{~m}), 1.84(\mathrm{~m})$ & 36.8 & $1.43(\mathrm{~m}), 1.85(\mathrm{~m})$ & 36.8 \\
\hline $\mathrm{C} 2$ & $1.93(\mathrm{~m}), 2.08(\mathrm{~m})$ & 27.4 & $1.95(\mathrm{~m}), 2.11(\mathrm{~m})$ & 27.4 \\
\hline $\mathrm{C} 3$ & $3.23(\mathrm{~m})$ & 88.5 & $3.26(\mathrm{~m})$ & 88.5 \\
\hline $\mathrm{C} 4$ & - & 40.3 & - & 40.3 \\
\hline $\mathrm{C} 5$ & $0.87(\mathrm{~m})$ & 55.4 & $0.89(\mathrm{~m})$ & 55.3 \\
\hline C6 & $1.51(\mathrm{~m}), 1.71(\mathrm{~m})$ & 21.2 & $1.49(\mathrm{~m}), 1.71(\mathrm{~m})$ & 21.2 \\
\hline $\mathrm{C} 7$ & $1.22(\mathrm{~m}), 1.61(\mathrm{~m})$ & 29.3 & $1.26(\mathrm{~m}), 1.61(\mathrm{~m})$ & 29.3 \\
\hline $\mathrm{C} 8$ & $3.24(\mathrm{~m})$ & 39.0 & $3.27(\mathrm{~m})$ & 38.9 \\
\hline C9 & - & 146.1 & - & 146.1 \\
\hline $\mathrm{C} 10$ & - & 40.5 & - & 40.3 \\
\hline $\mathrm{C} 11$ & $5.32(\mathrm{~m})$ & 111.1 & $5.34(\mathrm{~m})$ & 111.1 \\
\hline $\mathrm{C} 12$ & $2.48(2 \mathrm{H}, \mathrm{m})$ & 32.8 & $2.50(2 \mathrm{H}, \mathrm{m})$ & 32.8 \\
\hline $\mathrm{C} 13$ & - & 56.2 & - & 56.3 \\
\hline $\mathrm{C} 14$ & - & 42.6 & - & 42.6 \\
\hline $\mathrm{C} 15$ & $2.21(\mathrm{~m}), 2.33(\mathrm{~m})$ & 52.5 & $2.22(\mathrm{~m}), 2.37(\mathrm{~m})$ & 52.5 \\
\hline $\mathrm{C} 16$ & - & 213.6 & - & 213.6 \\
\hline $\mathrm{C} 17$ & $2.80(\mathrm{~s})$ & 61.3 & $2.81(\mathrm{~s})$ & 61.3 \\
\hline $\mathrm{C} 18$ & - & 176.5 & - & 176.5 \\
\hline C19 & $1.42(3 \mathrm{H}, \mathrm{s})$ & 22.6 & $1.42(3 \mathrm{H}, \mathrm{s})$ & 22.6 \\
\hline $\mathrm{C} 20$ & - & 83.6 & - & 83.6 \\
\hline
\end{tabular}




\begin{tabular}{ccccc} 
& & & \multicolumn{2}{c}{ Table 1 (continued) } \\
\hline $\mathrm{C} 21$ & $1.48(3 \mathrm{H}, \mathrm{s})$ & 28.8 & $1.50(3 \mathrm{H}, \mathrm{s})$ & 28.8 \\
$\mathrm{C} 22$ & $1.68(\mathrm{~m}), 1.81(\mathrm{~m})$ & 38.9 & $1.65(\mathrm{~m}), 1.82(\mathrm{~m})$ & 38.9 \\
$\mathrm{C} 23$ & $1.37(\mathrm{~m}), 1.66(\mathrm{~m})$ & 22.7 & $1.31(\mathrm{~m}), 1.64(\mathrm{~m})$ & 22.7 \\
$\mathrm{C} 24$ & $1.50(2 \mathrm{H}, \mathrm{m})$ & 38.6 & $1.52(2 \mathrm{H}, \mathrm{m})$ & 38.6 \\
$\mathrm{C} 25$ & $1.42(\mathrm{~m})$ & 30.5 & $1.41(\mathrm{~m})$ & 30.5 \\
$\mathrm{C} 26$ & $0.90(3 \mathrm{H} \mathrm{d} \mathrm{7.3})$ & 22.8 & $0.91(3 \mathrm{H} \mathrm{d} \mathrm{7.3)}$ & 22.7 \\
$\mathrm{C} 27$ & $0.91(3 \mathrm{H} \mathrm{d} \mathrm{7.3})$ & 22.9 & $0.91(3 \mathrm{H} \mathrm{d} \mathrm{7.3)}$ & 22.8 \\
$\mathrm{C} 28$ & $1.38(3 \mathrm{H}, \mathrm{s})$ & 27.7 & $1.39(3 \mathrm{H}, \mathrm{s})$ & 26.8 \\
$\mathrm{C} 29$ & $1.10(3 \mathrm{H}, \mathrm{s})$ & 17.9 & $1.12(3 \mathrm{H}, \mathrm{s})$ & 17.9 \\
$\mathrm{C} 30$ & $0.95(3 \mathrm{H}, \mathrm{s})$ & 18.8 & $0.90(3 \mathrm{H}, \mathrm{s})$ & 18.8 \\
\hline
\end{tabular}

Table 2

${ }^{1} \mathrm{H}$ and ${ }^{13} \mathrm{C}$ NMR spectral data $(400 / 100 \mathrm{MHz})$ of the sugar moieties of compounds $\mathbf{1}$ and $\mathbf{2}$ in $\mathrm{C}_{5} \mathrm{D}_{5} \mathrm{~N}$

\begin{tabular}{|c|c|c|c|c|}
\hline \multirow{2}{*}{ No. } & \multicolumn{2}{|c|}{1} & \multicolumn{2}{|c|}{2} \\
\hline & $\delta_{\mathrm{H}}$ & $\delta_{\mathrm{C}}$ & $\delta_{\mathrm{H}}$ & $\delta_{\mathrm{C}}$ \\
\hline Glc/Xyl-1' & $4.97(\mathrm{~d}, 8.0)$ & 105.6 & $4.75(\mathrm{~d}, 7.3)$ & 105.5 \\
\hline $2^{\prime}$ & $4.02(\mathrm{~m})$ & 88.1 & $4.03(\mathrm{~m})$ & 85.5 \\
\hline $3^{\prime}$ & $4.07(\mathrm{~m})$ & 74.3 & $4.20(\mathrm{~m})$ & 76.9 \\
\hline $4^{\prime}$ & $4.21(\mathrm{~m})$ & 79.3 & $4.26(\mathrm{~m})$ & 78.5 \\
\hline $5^{\prime}$ & $4.12(\mathrm{~m})$ & 76.0 & $3.66(\mathrm{~m}), 4.40(\mathrm{~m})$ & 64.6 \\
\hline $6^{\prime}$ & $4.20(\mathrm{~m}), 4.42(\mathrm{~m})$ & 62.7 & & \\
\hline Glc-1" & $5.25(\mathrm{~d}, 8.0)$ & 106.2 & $5.26(\mathrm{~d}, 8.4)$ & 106.2 \\
\hline $2 "$ & $4.01(\mathrm{~m})$ & 74.8 & $4.00(\mathrm{~m})$ & 75.7 \\
\hline $3 "$ & $4.26(\mathrm{~m})$ & 76.5 & $4.18(\mathrm{~m})$ & 76.5 \\
\hline $4 "$ & $4.37(\mathrm{~m})$ & 79.1 & $4.32(\mathrm{~m})$ & 79.1 \\
\hline $5 "$ & $3.96(\mathrm{~m})$ & 73.6 & $4.02(\mathrm{~m})$ & 76.2 \\
\hline $6 "$ & $4.24(\mathrm{~m}), 4.49(\mathrm{~m})$ & 62.6 & $4.32(\mathrm{~m}), 4.47(\mathrm{~m})$ & 62.7 \\
\hline Glc/Xyl-1"' & $5.03(\mathrm{~d}, 8.0)$ & 103.9 & $5.16(\mathrm{~d}, 7.9)$ & 105.8 \\
\hline $2^{\prime \prime \prime}$ & $4.14(\mathrm{~m})$ & 72.1 & $4.03(\mathrm{~m})$ & 73.7 \\
\hline 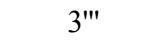 & $4.20(\mathrm{~m})$ & 88.9 & $4.16(\mathrm{~m})$ & 87.9 \\
\hline 4"' & $4.15(\mathrm{~m})$ & 70.3 & $4.06(\mathrm{~m})$ & 70.2 \\
\hline $5^{\prime \prime \prime}$ & $4.06(\mathrm{~m})$ & 76.9 & $3.58(\mathrm{~m}), 4.20(\mathrm{~m})$ & 67.1 \\
\hline 6"' & $4.17(\mathrm{~m}), 4.52(\mathrm{~m})$ & 61.9 & & \\
\hline
\end{tabular}




\begin{tabular}{|c|c|c|c|c|}
\hline & & & & Table 2 (continued) \\
\hline Glc-1"'" & $5.28(\mathrm{~d}, 7.6)$ & 106.4 & $5.29(\mathrm{~d}, 7.9)$ & 106.4 \\
\hline $2^{\prime \prime \prime \prime}$ & $4.08(\mathrm{~m})$ & 76.3 & $4.01(\mathrm{~m})$ & 76.0 \\
\hline $3^{\prime \prime \prime \prime}$ & $4.18(\mathrm{~m})$ & 78.9 & $4.21(\mathrm{~m})$ & 78.9 \\
\hline $4 " '$ & $4.16(\mathrm{~m})$ & 72.2 & $4.24(\mathrm{~m})$ & 72.2 \\
\hline $5^{\prime \prime \prime}$ & $3.87(\mathrm{~m})$ & 78.7 & $3.93(\mathrm{~m})$ & 78.7 \\
\hline 6"'" & $4.30(\mathrm{~m}), 4.55(\mathrm{~m})$ & 63.0 & $4.23(\mathrm{~m}), 4.52(\mathrm{~m})$ & 62.8 \\
\hline Glc-1"'"' & $5.14(\mathrm{~d}, 7.2)$ & 106.2 & $5.00(\mathrm{~d}, 7.4)$ & 103.1 \\
\hline $2 " ' " '$ & $4.06(\mathrm{~m})$ & 75.7 & $4.09(\mathrm{~m})$ & 75.6 \\
\hline 3"'"' & $4.22(\mathrm{~m})$ & 78.5 & $4.23(\mathrm{~m})$ & 78.8 \\
\hline 4"'"' & $4.18(\mathrm{~m})$ & 72.1 & $4.18(\mathrm{~m})$ & 72.1 \\
\hline $5 " '+1$ & $3.96(\mathrm{~m})$ & 78.7 & $4.04(\mathrm{~m})$ & 78.7 \\
\hline $6^{\prime \prime \prime " '}$ & $4.24(\mathrm{~m}), 4.40(\mathrm{~m})$ & 62.9 & $4.30(\mathrm{~m}), 4.55(\mathrm{~m})$ & 62.9 \\
\hline
\end{tabular}

The cytotoxic activities of compounds $\mathbf{1}$ and $\mathbf{2}$ against MGC-803 (human gastric carcinoma cell line), PC-3M (human prostate cancer cell line), and MCF-7 (human breast cancer cell line) were evaluated. Compound $\mathbf{1}$ displayed good cytotoxic activity against MGC-803 and PC-3M cell lines ( $\mathrm{IC}_{50} 31.86$ and $87.65 \mu \mathrm{g} / \mathrm{mL}$, respectively). Compound 2 had adequate inhibitory effects against the MGC-803 cell line $\left(\mathrm{IC}_{50} 71.21 \mu \mathrm{g} / \mathrm{mL}\right.$ ) and moderate cytotoxic activity against the PC-3M cell line $\left(\mathrm{IC}_{50}>100 \mu \mathrm{g} / \mathrm{mL}\right)$. However, compounds 1 and 2 had weak effects on MCF-7 cell proliferation with an inhibition rate of $25.3 \%$ and $26.9 \%$ at $100 \mu \mathrm{g} / \mathrm{mL}$, respectively. Furthermore, 5-Fluorouracil showed moderate inhibitory effect $\left(\mathrm{IC}_{50}>100 \mu \mathrm{g} / \mathrm{mL}\right)$ against the three cell lines. Treatment with the two compounds resulted in significant changes in the morphology of MGC-803 and PC-3M cells (Fig. 3).
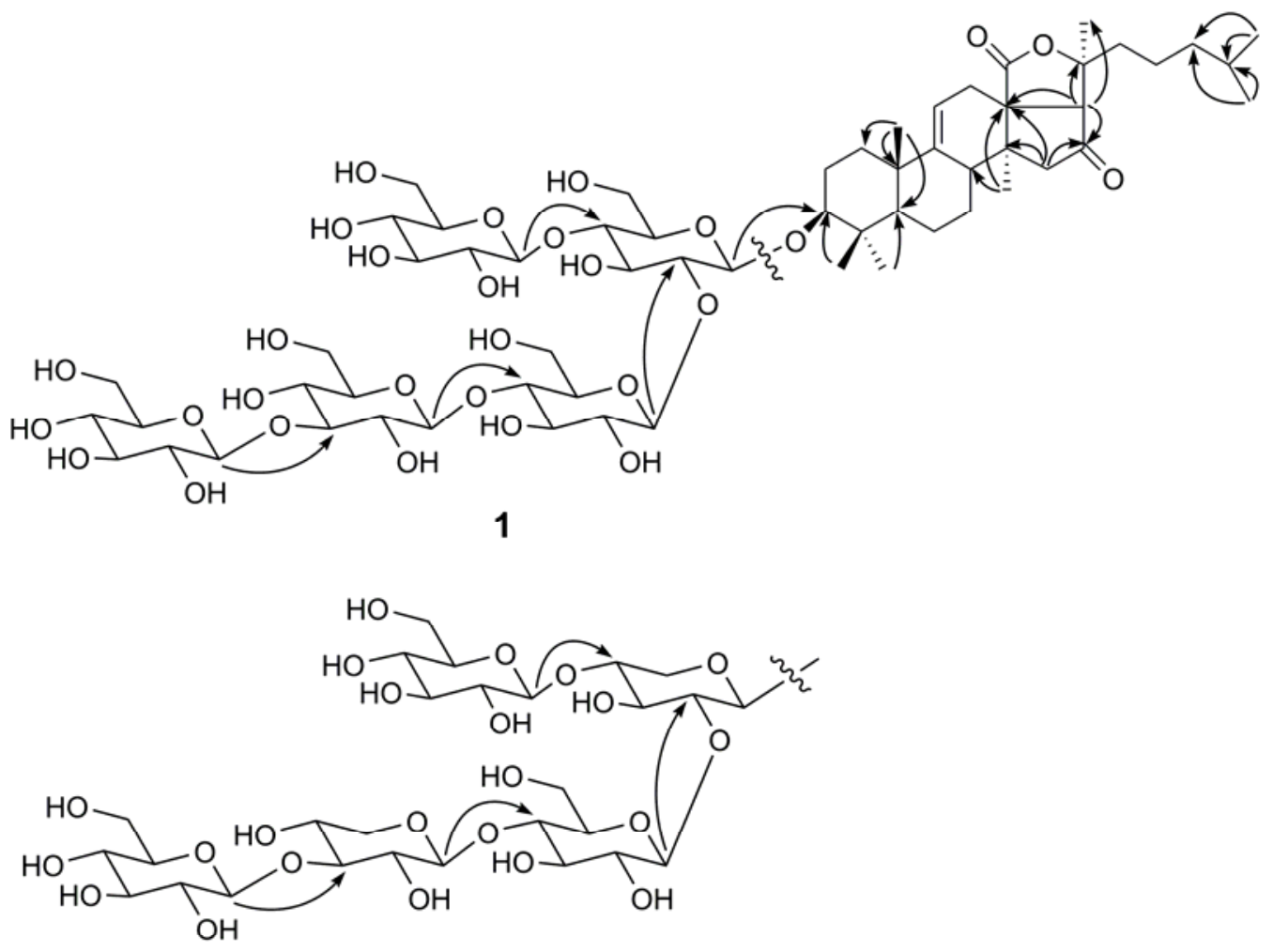

2

Fig. 2 - Key HMBC correlations of compounds $\mathbf{1}$ and $\mathbf{2}$. 


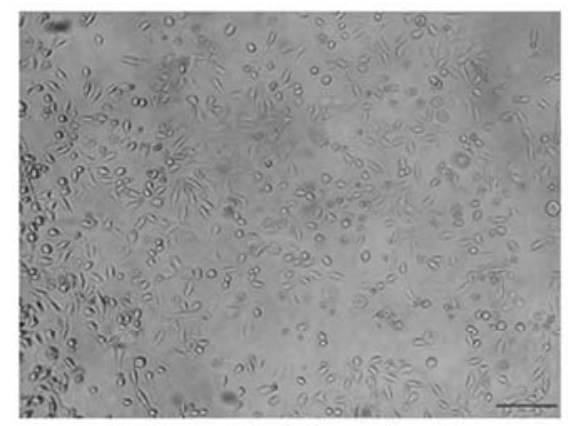

MGC-803 (control)

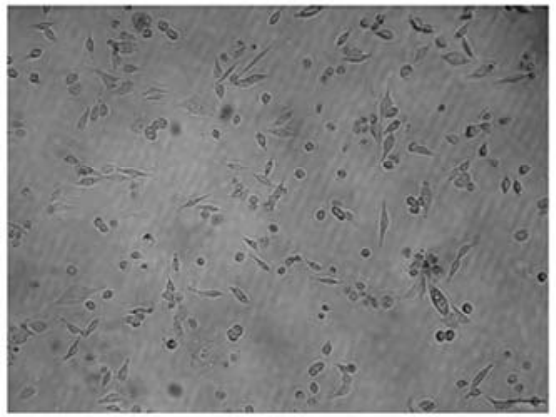

PC-3M (control)

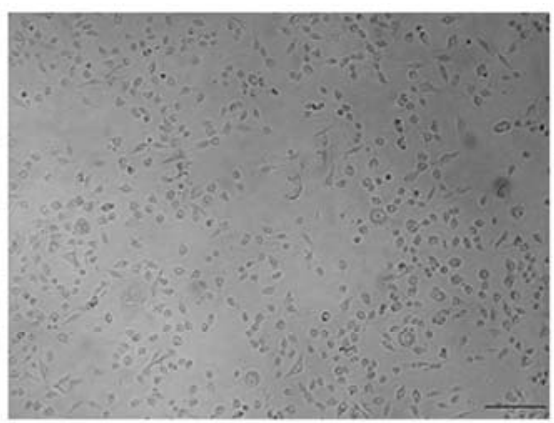

MGC-803 (1)

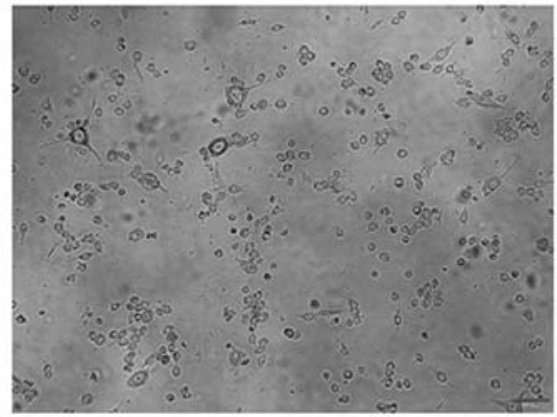

$\mathrm{PC}-3 \mathrm{M}(1)$

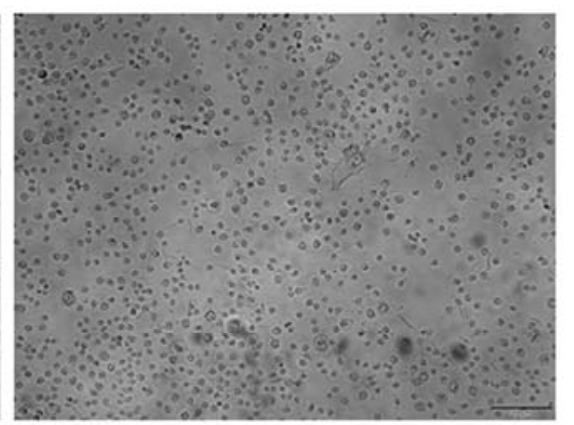

MGC-803 (2)

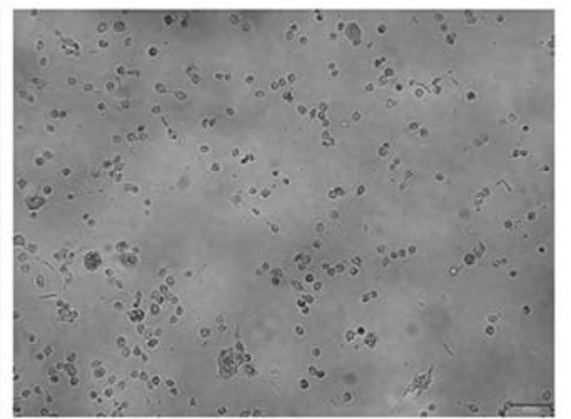

PC-3M (2)

Fig. 3 - Morphological changes in MGC-803 and PC-3M cells.

\section{EXPERIMENTAL}

\section{Viscera material}

A. japonicus were collected in May 2017 close to Penglai-Changdao, China, and identified by Professor Kechun Liu from the Biology Institute of Qilu University of Technology (Shandong Academy of Sciences). The separated viscera were kept in zip-lock plastic bags, which were snap-frozen, transferred to the laboratory, and stored at $-20^{\circ} \mathrm{C}$. A voucher specimen (No.SWS0511AD) was deposited at the Key Laboratory for Drug Screening Technology of the Biology Institute.

\section{Experimental apparatus}

IR spectra were obtained using a Thermo Nicolet iS10 spectrophotometer (MA, USA) with $\mathrm{KBr}$ disks. HR-ESI-MS data were obtained using an Agilent 6520 series Q-TOF mass spectrometer (Palo Alto, CA, USA). NMR spectra were acquired from a Bruker Avance III 400-MHz spectrometer (Karlsruhe, Germany) in pyridine- $d_{5}$ solutions. Sugar analysis was performed by HPLC using a Hitachi L-2130 pump (Tokyo, Japan) coupled to a Hitachi L-2400 UV-vis detector (Tokyo, Japan).

\section{Extraction and isolation}

The dried viscera of $A$. japonicus were minced and homogenized, and the powders $(200 \mathrm{~g})$ were extracted three times at reflux with $\mathrm{MeOH}$ ( $2 \mathrm{~h}$ each time). The extracts were pooled and concentrated in a rotary evaporator at $45^{\circ} \mathrm{C}$ under reduced pressure to remove the methanol. The residual sample was suspended in water $(200 \mathrm{~mL})$ and loaded onto a column containing pretreated D101 macroporous adsorption resin (0.3- to $1.25-\mathrm{mm}$ particle size, Nankai University Chemical Plant, Tianjin, China). Subsequently, the column was eluted with four BV of redistilled water and six BV of $30 \%$ and $60 \%$ ethanol. The saponin-rich fraction was eluted with six BV of $90 \%$ ethanol, concentrated, and dried. The saponin fraction (4.1g) was applied to Sephadex LH-20 $\left(\mathrm{CH}_{2} \mathrm{Cl}_{2} / \mathrm{MeOH}, 1: 1\right)$, yielding three fractions (Fr. 1-3). Fraction 2 (2.2 g) was eluted with $\mathrm{CH}_{2} \mathrm{Cl}_{2}-\mathrm{MeOH}(100: 2-100: 80, \mathrm{v} / \mathrm{v})$ in a silica gel column, thereby resulting in 11 fractions (Fr. 2.1- Fr. 2.11). Fr. 2.10 $(113 \mathrm{mg})$ was eluted with $\mathrm{ACN}-\mathrm{H}_{2} \mathrm{O}(10 \%-60 \%$, v/v) based on RP-18 TLC analysis in an ODS column (Spherical $\mathrm{C}_{18}, 120 \AA$, 30-50 $\mu \mathrm{m}$, Daiso, Osaka, Japan), resulting in compounds 1 (16.7 $\mathrm{mg}$ ) and 2 (12.4 mg).

Apostichoposide D (1): White amorphous powder; IR (KBr) vmax cm ${ }^{-1}: 3,331,2,924,1,751,1,379,1,070 ;{ }^{1} \mathrm{H}$ NMR and ${ }^{13} \mathrm{C}$ NMR $\left(\mathrm{C}_{5} \mathrm{D}_{5} \mathrm{~N}\right)$ spectral data (Tables 1 and 2 ); HR-ESI-MS $\mathrm{m} / \mathrm{z}: \quad 1235.5951 \quad\left[\mathrm{M}-\mathrm{H}-\mathrm{CO}_{2}\right]^{-}$(calcd for $\mathrm{C}_{59} \mathrm{H}_{95} \mathrm{O}_{27}, 1235.6061$ ), 255.2322 and 555.2825 (two ring-cleavage products of $\left[\mathrm{M}_{\text {sugar chain }}-\mathrm{H}\right]^{-}$)

Apostichoposide E (2): White amorphous powder; IR (KBr) vmax cm ${ }^{-1}: 3,284,2,922,1,749,1,362,1,066 ;{ }^{1} \mathrm{H}$ NMR and ${ }^{13} \mathrm{C}$ NMR $\left(\mathrm{C}_{5} \mathrm{D}_{5} \mathrm{~N}\right)$ spectral data (Tables 1 and 2 ); HR-ESI-MS m/z: 1,219.5687 [M-H] ${ }^{-}$(calcd for $\mathrm{C}_{58} \mathrm{H}_{91} \mathrm{O}_{27}$, 1,219.5748), 369.2458 and 399.2538 (two ring-cleavage products of $\left[\mathrm{M}_{\text {sugar chain }}-\mathrm{H}+\mathrm{H}_{2} \mathrm{O}\right]^{-}$)

\section{Acid hydrolysis of compounds 1 and 2}

The configuration of sugars was determined using a previously published method with minor modification. ${ }^{18}$ Compounds 1 and $2(3 \mathrm{mg})$ were hydrolyzed with $1 \mathrm{M} \mathrm{HCl}$ $(4.0 \mathrm{~mL})$ and heated at $80^{\circ} \mathrm{C}$ for $4 \mathrm{~h}$. The reaction mixture was neutralized with $\mathrm{Na}_{2} \mathrm{CO}_{3}$ and filtered, and the filtrate was successively extracted with $\mathrm{CH}_{2} \mathrm{Cl}_{2}(3 \times 4.0 \mathrm{ml})$. Following evaporation under vacuum, the aqueous layer was concentrated to yield the sugar portion. The obtained sugar 
portion and L-cysteine methyl ester hydrochloride $(4 \mathrm{mg})$ were dissolved in pyridine $(1 \mathrm{~mL})$ and heated for $1 \mathrm{~h}$ at $60^{\circ} \mathrm{C}$. Subsequently, o-tolyl isothiocyanate $(100 \mu \mathrm{L})$ in pyridine $(1 \mathrm{~mL})$ was added to the mixture and heated for $1 \mathrm{~h}$. The reaction mixture $(2 \mathrm{~mL})$ was analyzed by HPLC and detected at $250 \mathrm{~nm}\left(\mathrm{ACN}: \mathrm{H}_{2} \mathrm{O}=10: 90 \sim 40: 60,1 \mathrm{~mL} / \mathrm{min}, 20 \mathrm{~min}\right)$. The sugars of each reactant were identified by comparing their retention times with those of actual samples: $t_{R}$ (min) D-glucose (10.61), D-xylose (11.28).

\section{Cytotoxicity assay by cell counting kit-8}

The assays were conducted as described previously. ${ }^{19}$ MGC-803, PC-3M, and MCF-7 cells were cultured in 96-well culture plates $\left(5 \times 10^{3}\right.$ cells per well $)$ in DEME and RPMI 1640 medium supplemented with $10 \%$ fetal bovine serum. Subsequently, the cells were treated with different concentrations $(100,50,25,12.5,6.25$, and $3.125 \mu \mathrm{g} / \mathrm{mL})$ of compounds 1 and 2 for $6 \mathrm{~h}$; 5-Fluorouracil was used as a positive control. The morphological changes of the treated cells were examined under an inverted microscope (Olympus, Tokyo, Japan). An aliquot of the cell counting kit-8 solution (10 $\mu \mathrm{L}$; CCK-8; Dojindo, Kyushu, Japan) was added to each well, and the cells were incubated for $2 \mathrm{~h}$ in a humidified atmosphere of $5 \% \mathrm{CO}_{2}$ at $37^{\circ} \mathrm{C}$. The absorbance of the solution was determined at $450 \mathrm{~nm}$ using a microplate spectrophotometer. Cell inhibitory rate was calculated using the following formula, Cell inhibitory rate $(\%)=\left[1-\mathrm{A}_{450}\right.$ (sample) $/ \mathrm{A}_{450}$ (control) $] \times 100$.

\section{CONCLUSIONS}

Triterpenoid glycosides were known as one of the main components in sea cucumber, which were suggested to be a kind of chemical defense molecules against potential predators. ${ }^{20-24}$ Viscera glycosides have especially attracted considerable attention due to their complex structures and physiological functions. Herein two holostane-type glycosides, apostichoposide $\mathrm{D}(\mathbf{1})$ and $\mathrm{E}(\mathbf{2})$, were isolated from the viscera of the Chinese sea cucumber $A$. japonicus. The structures of the two compounds were elucidated based on extensive spectroscopic analysis, including HR-MS, 1D and 2D NMR, and chemical analysis. They showed strong inhibitory activities against human gastric carcinoma MGC-803 cells and human prostate cancer PC-3M cells. Our study findings will assist in the industrial applications of sea cucumber viscera.

Acknowledgements: This study was financially supported by the Public Science and Technology Research Funds Projects of Ocean (grant number 201505030) and the Shandong Key Technical Development Projects (grant numbers 2015GSF121021 and 2016ZDJS06B01).

\section{REFERENCES}

1. V.A. Stonik, V.I. Kalinin and S.A. Avilov. J. Nat. Toxins 1999, 8, 235.

2. B. Sara, A. Farooq and S. Nazamid, Mar. Drugs, 2011, 9, 1761.

3. C. F. Li, X. C. Li, H. Li, S. J. Guo and X. B. Zhu, Chin. J. Oceanol Limnol, 2013, 31, 850.

4. M. Elbandy, J. Rho and R. Afifi, Eur. Food Res. Technol., 2014, 238, 1 .

5. Y. Bahrami, W. Zhang, T. Chataway and C. Franco, Mar. Drugs, 2014, 12, 4439.

6. V. I. Kalinin, A. S. Silchenko, S. A. Avilov, V. A. Stonik and A. V. Smirnov, Phytochem. Rev., 2005, 4, 221.

7. A. S. Silchenko, S. A. Avilov, A. I. Kalinovsky, P. S. Dmitrenok, V. I. Kalinin, J. Morre, M. L. Deinzer, C. Woodward and P. D. Collin, Can. J. Chem., 2007, 85, 626.

8. A. S. Silchenko, A. I. Kalinonovsky, S. A. Avilov, P. V. Andryjashenko, P. S. Dmitrenok, V. I. Kalinin and V. A., Stonik. Biochem. Syst. Ecol., 2012, 44, 53.

9. A. S. Silchenko, A. I. Kalinovsky, S. A. Avilov, P. V. Andryjaschenko, P. S. Dmitrenok, V. I. Kalinin, E. A. Martyyas and K. V. Minin, Nat. Prod. Commun., 2016, 11, 939.

10. P. L. Kiew and M. M. Don, Int. J. Food Sci. Nutr., 2012, 63, 616.

11. S.J . Shi, W. J. Feng, S. Hu, S. X. Liang, N. N. An and Y. J. Mao, Chin. J. Oceanol Limnol, 2016, 34, 549.

12. O. Y. Althunibat, B. H. Ridzwan, M. Taher, J. M. Daud, M. A. Ikeda and B. I. Zali, Eur. J. Sci. Res., 2009, 37, 376.

13. O. Y. Althunibat, B. H. Ridzwan, M. Taher, J. M. Daud, S. Jauhari Arief Ichwan and H. Qaralleh, Acta Biol Hung, 2013, 64, 10.

14. Y. Zhong, M. A. Khan and F. Shahidi, J. Agr. Food Chem., 2007, 55, 1188.

15. Y. Bahrami, W. Zhang and C. Franco, Mar. Drugs, 2014, 12, 2633.

16. Y. Bahrami and C. Franco, Mar. Drugs, 2015, 13, 597.

17. L. F. Yu, J. Xu, S. G. Chen, Y. Xue, J. F. Wang, Z. J. Li and C. H. Xue, J. Chin. Mass. Spectr. Soc., 2011, 32, 77

18. M. Amakura, M. Yoshimura, S. Morimoto, T. Yoshida, A. Tada, Y. Ito, T. Yamazaki, N. Sugimoto and H Akiyama, Chem. Pharm. Bull., 2016, 64, 78.

19. D. L. Liu, Y. Yang, Q. Liu and J. J. Wang, Med. Oncol., 2011, 28, 105.

20. P. Dong, C. Xue and Q Du, Acta Chromatogr., 2008, 20, 269.

21. H. Han, W. Zhang, Y. H. Yi, B. S. Liu, M. X. Pan and X. H. Wang, Chem. Biodivers., 2010, 7, 1764.

22. S. L. Zhang, L. Li, Y. H. Yi and P Sun, Nat. Prod. Res., 2006, 20, 399.

23. S. L. Zhang, L. Li, Y. H. Yi, Z. R. Zou and P. Sun, Mar. Drugs, 2004, 2, 185.

24. S. Y. Zhang, Y. H. Yi, H. F. Tang, L. Li, P. Sun and J. Wu, J. Asian Nat. Prod. Res., 2006, $8,1$. 
